\title{
THE INCIDENCE OF HEAVY METALS AND OTHER TOXIC ELEMENTS IN ROE DEER (Capreolus capreolus) TISSUES
}

\author{
Milica Živkov Baloš1 , Željko Mihaljev, Sandra Jakšić, Nadežda Prica, \\ Gospava Lazić, Miloš Kapetanov, Jasna Prodanov Radulović \\ Scientific Veterinary Institute "Novi Sad", Novi Sad
}

\section{Abstract}

Levels of lead $(\mathrm{Pb})$, cadmium $(\mathrm{Cd})$, arsenic (As), mercury $(\mathrm{Hg})$ and copper $(\mathrm{Cu})$ in the liver, kidney and muscle of 11 individual roe deer (Capreolus capreolus) were determined. The samples were prepared by microwave wet digestion. Content of investigated elements was determined by the method of coupled plasma with mass spectometry. The lead concentrations ranged from $<0.001$ (liver) to $8.455 \mathrm{mg} / \mathrm{kg}$ (meat), Cd concentrations ranged from 0.004 (muscle) to $0.818 \mathrm{mg} / \mathrm{kg}$ (kidney) and As concentrations ranged from 0.002 (liver) to $0.031 \mathrm{mg} / \mathrm{kg}$ (kidney). Concentrations of $\mathrm{Hg}$ in examined tissues (liver, kidney, muscle) were under limit of detection $(<0.001 \mathrm{mg} / \mathrm{kg})$. The concentration of copper in liver ranged from 3.913 to $104.08 \mathrm{mg} / \mathrm{kg}$. The results of this study showed that no samples exceeded maximum allowed levels for $\mathrm{Cd}, \mathrm{Hg}$, $\mathrm{As}$ and $\mathrm{Cu}$. $\mathrm{Pb}$ concentrations in muscle samples ranged from 0.008 to $8.455 \mathrm{mg} / \mathrm{kg}$. High concentrations of $\mathrm{Pb}$ in two muscle samples are most likely due to the proximity of hunting wound area, as lead was not detected in organ samples. The presence of some elements in the tissues of roe deer suggests the necessity of further research aimed at identifying the source of contamination in order to preserve the health of both humans and animals.

Keywords: lead, cadmium, mercury, arsenic, copper, tissues, roe deer

\footnotetext{
${ }^{1}$ Corresponding author: milica@niv.ns.ac.rs
} 


\title{
TEŠKI METALI I DRUGI TOKSIČNI ELEMENTI U TKIVIMA SRNA (Capreolus capreolus)
}

\author{
Milica Živkov Baloš, Željko Mihaljev, Sandra Jakšić, Nadežda Prica, \\ Gospava Lazić, Miloš Kapetanov, Jasna Prodanov Radulović \\ Naučni Institit za veterinarstvo "Novi Sad", Novi Sad
}

\section{Kratak sadržaj}

$\mathrm{U}$ ovom radu ispitivan je sadržaj olova $(\mathrm{Pb})$, kadmijuma $(\mathrm{Cd})$, arsena (As), žive $(\mathrm{Hg})$ i bakra $(\mathrm{Cu})$ u jetri, bubrezima i mišićnom tkivu, 11 srna. Uzorci su pripremljeni metodom mikrotalasne vlažne digestije. Sadržaj ispitivanih elemenata je određen metodom indukovano kuplovane plazme sa masenom detekcijom. Koncentracija $\mathrm{Pb}$ kretala se u intervalu od $<0,001$ (jetra) do $8,455 \mathrm{mg} / \mathrm{kg}$ (mišićno tkivo), dok se koncentracija Cd kretala od 0,004 (mišićno tkivo) do 0,818 mg/kg (bubreg). Koncentracija As je bila u rasponu od 0,002 (jetra) do $0,031 \mathrm{mg} / \mathrm{kg}$ (bubreg). Koncentracije $\mathrm{Hg} u$ ispitivanih tkivima (jetra, bubreg, mišić) je bila ispod granica detekcije metode $(<0,001 \mathrm{mg} / \mathrm{kg})$. Sadržaj bakra u jetri kretao se u intervalu od 3,913 do $104,08 \mathrm{mg} / \mathrm{kg}$. Izmerene vrednosti za sadržaj Cd, Hg, As i $\mathrm{Cu}$ u svim ispitivanim tkivima, a sadržaj $\mathrm{Pb}$ u jetri i bubrezima ne prelazi propisane maksimalno dozvoljene vrednosti. Koncentracije $\mathrm{Pb}$ u uzorcima mišićnog tkiva kretala se u rasponu od 0,008 do 8,455 mg/ $\mathrm{kg}$. Visoke koncentracije $\mathrm{Pb}$ u dva uzorka mišića, verovatno su posledica blizine mesta odstrelne rane, s obzirom na to da u uzorcima organa istih životinja nije detektovano $\mathrm{Pb}$. Zbog prisustva toksičnih elementa u tkivima i organima srna, neophodna su dalja istraživanje kako bi se identifikovali izvori kontaminacije, a u cilju očuvanja zdravlja ljudi i životinja. Ključne reči: olovo, kadmijum, živa, arsen, bakar, tkiva, srna

\section{INTRODUCTION}

Contamination of the environment with hazardous compounds and elements of anthropogenic origin is of increasing concern because of its effect on the entire biosphere, i.e., the micro-flora and -fauna of soils, plants and higher life, including humans and animals (Selenius et al., 1996). Many wild animals are exposed to diverse toxic substances by consuming contaminated plants and animals, or water, soil and air (Živkov Baloš et al., 2015). The accumulation of toxic heavy metals in plants and soil may increase the risk of transfer to 
herbivorous wild mammals and game animals or to livestock (Bilandžić et al., 2010). As animals can move freely and find their own food, the game is a link in the chain that accumulates pollutants from the environment. Monitors have recently been defined as organisms in which changes in known characteristics can be measured to assess the extent of environmental contamination, so that conclusions on the health implication for other species of the environment as a whole can be drawn. Monitors may provide information about environmental concentrations of essential and toxic metals of importance for life, displaying deficiency and toxicity, respectively (Selinus et al., 1996).

In order to fully understand the exposure of animals to many pollutants originating from the environment and to assess the harmful effect and estimate the risk, it is necessary to carry out a systematic study and gather data on degree and type of pollution, as well as distribution of hazardous chemicals in nature. Nowadays, a number of studies have been based on the determination of chemical contaminants in animal tissues and organs. As the result of these findings, it is possible to estimate the level of human exposure to negative effects of these pollutants. The monitoring and control of game meat safety should include control measures for live animals, control measures during hunting and after shooting, guidelines for official meat inspection, control measures for carcass processing and surveillance of chemical residues (Petrović et al., 2014).

Since it fulfils numerous criteria (e.g. widely geographic distribution, relatively small home range, territorial living and browsing nutrition strategy, huge availability of basic data, relatively simple sampling procedure) roe deer has been often mentioned in the literature as a good or even excellent monitor of toxic elements burdens on the environment (Pokorny, 2000).

The purpose of this study was to evaluate the concentration of environmental contaminants lead $(\mathrm{Pb})$, arsenic (As), mercury $(\mathrm{Hg})$, cadmium $(\mathrm{Cd})$ and copper $(\mathrm{Cu})$ in tissues of free-living roe deer in Serbia, as important information in performing assessments of the risk for both wildlife and humans. The obtained results were compared with relevant data reported from other countries.

\section{MATERIAL AND METHODS}

Samples of liver, kidney and meat of roe deer (Capreolus capreolus) shot by hunters were collected from hunting ground of Begeč settlement, municipality Novi Sad. Sampling of wild animal organs was performed during the 2013/2014 hunting season. Animals were selected according to neither sex nor age. Thus, liver and kidney samples were collected from each animal (total of 
11 animals). Upon collection, all samples were placed into labeled plastic bags and stored at $-18^{\circ} \mathrm{C}$ to avoid tissue degradation prior to analysis.

The samples $(1 \mathrm{~g})$ were prepared applying the microwave (Ethos, Labstation Microwave, Milestone), digestion method (14) with the use of the mixture $\mathrm{H}_{2} \mathrm{O}_{2} / \mathrm{HNO}_{3}(1: 4, \mathrm{v} / \mathrm{v})$. After this process, the samples were transferred to 50 $\mathrm{mL}$ volumetric flasks and diluted with deionized water. Analyses of $\mathrm{Pb}$ (NoGM, IT 0.1 s/P), Cd (NoG-M, IT 1 s/P), As (He-M, IT 1 s/P), Hg (NoG-M, IT $1 \mathrm{~s} / \mathrm{P})$ and $\mathrm{Cu}(\mathrm{He}-\mathrm{M}$, IT $0.1 \mathrm{~s} / \mathrm{P})$ were conducted by ICP-MS 7700 mass spectrometer (Agilent Technologies). Solutions used for calibration were prepared from commercial stock standard solutions with $1000 \mathrm{mg} / \mathrm{l}$ of each element (Accustandard). To calculate the recovery percentage, 6 samples of meat have been spiked with known amounts of $\mathrm{Cd}, \mathrm{As}, \mathrm{Hg}, \mathrm{Pb}$ and $\mathrm{Cu}$ analytical standards. The obtained results are presented in Table 1.

Table 1: Isotopes, limit of detection (LOD) and recovery rates for monitored elements

\begin{tabular}{|c|c|c|c|}
\hline Element & Isotope & LOD $(\mathbf{m g} / \mathbf{k g})$ & Recovery (\%) \\
\hline $\mathbf{C d}$ & ${ }^{111} \mathrm{Cd}$ & 0.001 & 96.1 \\
\hline $\mathbf{A s}$ & ${ }^{75} \mathrm{As}$ & 0.001 & 100.4 \\
\hline $\mathbf{H g}$ & ${ }^{201} \mathrm{Hg}$ & 0.001 & 83.7 \\
\hline $\mathbf{P b}$ & ${ }^{208} \mathrm{~Pb}$ & 0.001 & 88.1 \\
\hline $\mathbf{C u}$ & ${ }^{63} \mathrm{Cu}$ & 0.001 & 102.9 \\
\hline
\end{tabular}

Statistical analysis was performed by the STATISTICA 12 software package, version 16.0. Data were grouped according to tissue and presented as mean \pm standard error, minimum and maximum values.

\section{RESULTS AND DISCUSSION}

Average values of toxic and trace elements obtained in this study for the livers, kidneys and meat of all investigated roe deer are summarized in Table 2 . The obtained values were compared with highest permissible hygienic limits for risk elements according to the maximum allowed levels (MAL) of particular contaminant in food in the Republic of Serbia (Official Gazette, 2011).

The results were compared with the results reported by other authors from our and other countries. Beside that comparison, a collation with some other countries could be interesting as well. An overview of some previous articles addressing toxic elements levels in tissues of free living roe deer (Capreolus 
capreolus) and red deer (Cervus elaphus) is presented in Table 3.

Table 2. Toxic elements concentrations $(\mathrm{mg} / \mathrm{kg})$ in different tissues of roe deer

\begin{tabular}{|c|c|c|c|c|c|c|}
\hline \multirow[t]{2}{*}{ Material } & \multirow[t]{2}{*}{$\mathrm{n}$} & $\mathrm{Cd}$ & As & $\mathrm{Hg}$ & $\mathbf{P b}$ & $\mathbf{C u}$ \\
\hline & & \multicolumn{4}{|c|}{$\begin{array}{c}\text { Mean } \pm \text { S.E. } \\
\text { Range }\end{array}$} & \\
\hline Liver & 11 & $\begin{array}{c}0.0527 \pm 0.043 \\
0.005-0.110\end{array}$ & $\begin{array}{c}0.008 \pm 0.006 \\
0.002-0.017\end{array}$ & $<0.001$ & $\begin{array}{l}0.077 \pm 0.092 \\
<0.001-0.222\end{array}$ & $\begin{array}{c}28.071 \pm 34.026 \\
3.913-104.08\end{array}$ \\
\hline Kidney & 11 & $\begin{array}{c}0.465 \pm 0.224 \\
0.166-0.818\end{array}$ & $\begin{array}{c}0.014 \pm 0.008 \\
0.005-0.031\end{array}$ & $<.0 .001$ & $\begin{array}{c}0.094 \pm 0.107 \\
<0.001-0.2900\end{array}$ & $\begin{array}{c}15.871 \pm 6.698 \\
0.6890-28.390\end{array}$ \\
\hline Muscle & 4 & $\begin{array}{c}0.005 \pm 0.008 \\
0.004-0.008\end{array}$ & $\begin{array}{c}0.014 \pm 0.004 \\
0.01-0.02\end{array}$ & $<.0 .001$ & $0.008-8.455$ & $\begin{array}{c}4.2305 \pm 0.9411 \\
3.393-5.568\end{array}$ \\
\hline MAL & $\begin{array}{r}\mathrm{mg} / \\
\mathrm{kg}\end{array}$ & $\begin{array}{l}\text { liver } 0.50 \\
\text { kidney } 1.0 \\
\text { meat } 0.05\end{array}$ & $\begin{array}{l}\text { liver } 0.50 \\
\text { kidney } 0.50 \\
\text { meat } 0.10\end{array}$ & $\begin{array}{c}\text { liver } 0.10 \\
\text { kidney } 0.10 \\
\text { meat } 0.03\end{array}$ & $\begin{array}{c}\text { liver } 0.50 \\
\text { kidney } 0.50 \\
\text { meat } 0.10\end{array}$ & liver 80.0 \\
\hline
\end{tabular}

MAL -Maximum allowed level (Official Gazette, Republic of Serbia, 2011)

Concentrations of As, $\mathrm{Cd}$ and $\mathrm{Hg}$ in liver, kidney and muscle samples of roe deer did not exceed the MAL in either of the examined samples (Table 2).

The highest Cd-contamination (average value $0.465 \mathrm{mg} / \mathrm{kg}$ ) was recorded in the kidneys of roe deer. Somewhat lower Cd levels were found in the liver $(0.0527 \mathrm{mg} / \mathrm{kg})$, while muscles were the least contaminated $(0.005 \mathrm{mg} / \mathrm{kg})$. The lowest and highest average concentrations of As were measured in liver (average value $0.008 \mathrm{mg} / \mathrm{kg}$ ) and kidney samples $(0.031 \mathrm{mg} / \mathrm{kg}$ ), respectively. Mercury $(\mathrm{Hg})$ was not detected in any of the investigated samples. Kidneys of roe deer revealed higher $\mathrm{Pb}$-contamination than liver (average values 0.094 $\mathrm{mg} / \mathrm{kg}$ in kidney and $0.077 \mathrm{mg} / \mathrm{kg}$ in liver). The $\mathrm{Pb}$ content in two muscle samples of roe deer was very high. High $\mathrm{Pb}$ concentrations measured in muscle samples are probably due to the proximity of gunshot wound, especially since such enormously high level of $\mathrm{Pb}$ in the examined muscle sample show a strong discrepancy with respect to $\mathrm{Pb}$ values in the liver and kidney (lead was not detected in samples of these organs). The maximum permissible level for $\mathrm{Cu}$ is prescribed only for liver $(80 \mathrm{mg} / \mathrm{kg})$. The average $\mathrm{Cu}$ level detected in the liver was $28.071 \pm 34.026 \mathrm{mg} / \mathrm{kg}$, while the value exceeding MAL (104.08 mg/ $\mathrm{kg}$ ) was recorded in only one sample. 
Table 3. Content of toxic elements $(\mathrm{mg} / \mathrm{kg})$ in different tissues of roe deer and red deer according to various authors

\begin{tabular}{|c|c|c|c|c|c|c|}
\hline \multirow[t]{2}{*}{ Material } & As & $\mathrm{Cd}$ & $\mathrm{Hg}$ & $\mathrm{Pb}$ & $\mathrm{Cu}$ & $\begin{array}{l}\text { Source, species } \\
\text { and country }\end{array}$ \\
\hline & \multicolumn{6}{|c|}{$\begin{array}{l}\text { Mean } \pm \text { S.E. } \\
\text { Range }\end{array}$} \\
\hline Liver & \multirow{3}{*}{ n.i. } & $\begin{array}{l}0.568 \pm 0.502 \\
0.015-2.306\end{array}$ & \multirow{3}{*}{ n.i. } & \multirow{3}{*}{ n.i. } & \multirow{3}{*}{ n.i. } & \multirow{3}{*}{$\begin{array}{l}\text { Pompe -Gotal J. } \\
\text { and Prevendar Cr- } \\
\text { nić A. (2002) } \\
\text { Capreolus capreolus } \\
\text { Croatia }\end{array}$} \\
\hline Kidney & & $\begin{array}{l}4.905 \pm 6.395 \\
0.223-27.686\end{array}$ & & & & \\
\hline Muscle & & $\begin{array}{l}0.018 \pm 0.019 \\
0.003-0.065\end{array}$ & & & & \\
\hline Liver & \multirow{3}{*}{ n.i. } & $\begin{array}{c}1.06 \pm 0.77 \text { (yearlings) } \\
3.92 \pm 0.88 \text { ( } 2 \text { year and more) }\end{array}$ & \multirow{3}{*}{ n.i. } & $\begin{array}{l}0.71 \pm 0.65 \\
<0.05-9.3\end{array}$ & \multirow{3}{*}{ n.i. } & \multirow{3}{*}{$\begin{array}{l}\text { Pokorny B. and Riba- } \\
\text { rič-Lasnik C. (2000) } \\
\text { Capreolus capreolus } \\
\text { Slovenia }\end{array}$} \\
\hline Kidney & & $\begin{array}{c}7.13 \pm 4.43 \text { (yearlings) } \\
22.73 \pm 8.92(2 \text { year and more) }\end{array}$ & & $\begin{array}{l}0.03 \pm 0.01 \\
<0.05-0.20\end{array}$ & & \\
\hline Muscle & & $\begin{array}{c}0.03 \pm 0.02 \text { (yearlings) } \\
0.04 \pm 0.01 \text { ( } 2 \text { year and more }) \\
\end{array}$ & & $\begin{array}{l}0.05 \pm 0.03 \\
<0.05-0.55 \\
\end{array}$ & & \\
\hline Liver & \multirow{3}{*}{ n.i. } & $0.21 \pm 0.10$ & \multirow{3}{*}{ n.i. } & $1.40 \pm 0.01$ & \multirow{3}{*}{ n.i. } & \multirow{3}{*}{$\begin{array}{c}\text { Kottferová J. and } \\
\text { Koréneková B. (1998) } \\
\text { Capreolus capreolus } \\
\text { Slovakia }\end{array}$} \\
\hline Kidney & & $2.63 \pm 2.24$ & & $0.25 \pm 0.18$ & & \\
\hline Muscle & & $0.02 \pm 0.03$ & & $0.12 \pm 0.03$ & & \\
\hline Liver & \multirow{3}{*}{ n.i. } & $0.70 \pm 0.39^{*}$ & \multirow{3}{*}{ n.i. } & $0.17 \pm 0.11^{\star}$ & $59 \pm 41^{*}$ & \multirow{3}{*}{$\begin{array}{l}\text { Jarzyńsla G. and } \\
\text { Falandysz J. (2011) } \\
\text { Cervus elaphus } \\
\text { Poland }\end{array}$} \\
\hline Kidney & & $12 \pm 8^{*}$ & & $0.30 \pm 0.26^{*}$ & $21 \pm 4^{*}$ & \\
\hline Muscle & & $0.22 \pm 0.13^{\star}$ & & $0.18 \pm 0.34^{*}$ & $11 \pm 4^{*}$ & \\
\hline Kidney & n.i. & $\begin{array}{l}2.071 \pm 0.216 \\
0.010-22.076\end{array}$ & n.i. & n.i. & n.i. & $\begin{array}{c}\text { Beiglböck C. et } \\
\text { al. (2002) } \\
\text { Capreolus capreolus } \\
\text { Austria }\end{array}$ \\
\hline Liver & \multirow{3}{*}{ n.i. } & $0.005-0.50$ & \multirow{3}{*}{ n.i. } & $0.077-0.108$ & \multirow{3}{*}{ n.i. } & \multirow{3}{*}{$\begin{array}{c}\text { Bilandžić et al. (2009) } \\
\text { Cervus elaphus } \\
\text { Croatia }\end{array}$} \\
\hline Kidney & & $2.28-5.91$ & & $0.058-3.77$ & & \\
\hline Muscle & & $0.005-0.80$ & & $0.04-6.69$ & & \\
\hline Liver & \multirow{3}{*}{ n.i. } & $0.08-0.79$ & $0.01-0.03$ & \multirow{3}{*}{ n.i. } & \multirow{3}{*}{ n.i. } & \multirow{3}{*}{$\begin{array}{c}\text { Petrović et al. (2013) } \\
\text { Cervus elaphus } \\
\text { Serbia }\end{array}$} \\
\hline Kidney & & $0.03-4.99$ & $0.01-0.10$ & & & \\
\hline Muscle & & n.i. & n.i. & & & \\
\hline Liver & n.i. & \multirow{3}{*}{ n.i. } & n.i. & $<0.05-9.30$ & \multirow{3}{*}{ n.i. } & \multirow{3}{*}{$\begin{array}{c}\text { Pokorny (2000) } \\
\text { Capreolus capreolus } \\
\text { Slovenia }\end{array}$} \\
\hline Kidney & $<0.02-0.43$ & & $<0.01-0.69$ & n.i. & & \\
\hline Muscle & n.i. & & n.i. & n.i. & & \\
\hline
\end{tabular}

Legend: n.i.- not investigated; ${ }^{\star}(d r y$ weight $)$ 
Similar results for $\mathrm{Cd}$ and $\mathrm{Pb}$ distribution were obtained by other authors, but our results for $\mathrm{Cd}$ concentrations are markedly lower as compared with other investigations (Table 3). Since the age was not taken into account in data interpretation in the majority of cited studies (Table 3), the levels of toxic element could not be directly compared with our research. Secondly, the bioindicative approach was emphasized in our investigation, but many of cited studies were chosen in the vicinity of local pollution sources (smelters, industrial and mining areas). Finally, some differences between species must be outlined. Red deer (Cervus elaphus) whose anatomy of the digestive tract is adjusted to the intake of wide spectrum of feed, receives more wood species ( $35 \%$ of the feed in summer, $30 \%$ of the feed amount in winter). Roe deer whose digestive tract is only poorly adjusted to the digestion of cellulose, prefers young summer plants, herbs, fruits (they have narrow leaves and retain less falling particles) but more wide-leaved feed (herbs, summer plants which retain more deposited pollutants) than the red deer. This fact is likely to be the main reason of the inter-species differences (Kottferová and Koréneková B., 1998).

\section{CONLUSIONS}

Average as well as maximum concentrations of toxic elements in the majority tissue samples examined during our investigation did not exceed the maximum permissible levels and the levels measured in tissues of European free-living roe deer. The levels of investigated toxic elements are well below the concentrations considered dangerous for animal's health. However, high concentrations of some toxic elements still confirm the imperative of imposing relevant control program that will include veterinary officials as well as hunters and other subjects involved in game meat chain.

\section{AKNOWLEDGMETS}

The presented work is part of the research done in the project TR31084 granted by the Serbian Ministry of Education, Science and Technological Development

\section{REFERENCES}

1. Beiglböck C., Steineck T., Tataruch F., Ruf T.: Environmental cadmium induces histopathological changes in kidneys of roe deer. Environmental Toxicology and Chemistry, 21, 9, 1811-1816, 2002.

2. Bilandžić N., Sedak M., Vratarić D., Perić T. and Šimić B.: Lead and cadmi- 
um in red deer and wild boar from different hunting grounds in Croatia. Science of the Total Environment 407, 4243-4247, 2009.

3. Bilandžić N., Sedak M., Đokić M., Šimić B.: Wild boar tissue levels of cadmium, lead and mercury in seven regions of continental Croatia. Bull Environ Contam Toxicol 84, 738-743, 2010.

4. Jarzyńska G., Falandysz J.: Selenium and 17 other largely essential and toxic metals in muscle and organ meats of Red Deer (Cervus elaphus) - Consequences to human health. Environment International, 37, 882-888, 2011.

5. Kottferová J., Koréneková B.: Distribution of $\mathrm{Cd}$ and $\mathrm{Pb}$ in the Tissues and Organs of Free-Living Animals in the Territory of Slovakia. Bull. Environ. Contam. Toxicol, 60, 171-176, 1998.

6. Official Gazette. Pravilnik o maksimalno dozvoljenim količinama ostataka sredstava za zaštitu bilja u hrani i hrani za životinje i o hrani i hrani za životinje za koju se utvrđuju maksimalno dozvoljene količine ostataka sredstava za zaštitu bilja. Official Gazette Republic of Serbia 28:Part 3, 2011.

7. Petrović J., Mirčeta J., Antić D., Pušić I., Urošević M.: Suggested model for monitoring and control of foodborne pathogens in wild boar's meat. Archives of Veterinary Medicine, 7, 2, 57-69, 2014.

8. Petrović Z., Vranić D., Đinović-Stojanović J., Velebit B., Lukić M., Nikolić D.: Cadmium and mercury content in liver and kidneys of wild game caught in various regions of Serbia. International $52^{\text {th }}$ Meat Industry Conference, June 10-12, Belgrade, Serbia, 2013, 257-262 pp.

9. Pokorny B.: Roe deer Capreolus capreolus as an accumulative bioindicator of heavy metals in Slovenia. Web Ecology, 1, 54-62, 2000.

10. Pokorny B., Ribarič-Lasnik C.: Lead, Cadmium and Zinc in Tissues of Roe Deer (Capreolus capreolus)near the Lead Smelter in the Koroška Region (Northern Slovenia). Bull. Environ. Contam. Toxicol., 64, 20-26, 2000.

11. Pompe-Gotal J., Prevendar Crnić A.: Cadmium in tissues of roe deer ( $\mathrm{Ca}$ preolus capreolus) in Croatia. Veterinarski Arhiv 72, 6, 303-310, 2002.

12. Selinius O., Frank A., Galgan V: Biogeochemistry and metal biology. Geological Society, London, Special Publicatons, 113, 81-89, 1996.

13. Živkov-Balos M., Mihaljev Ž., Ljubojević D., Apić J.: Lead and cadmium in wild boar from different grounds in Serbia. In: Proceedings and Abstracts book of the International Symposium on animal science (ISAS) 2015 and $19^{\text {th }}$ International Congress on biotechnology in animal reproduction (ICBAR), Novi Sad, 09-11 September, 2015, ISBN: 978-067520-346-9, 83-87. 